\title{
REFLECTION ON APPLICATION OF ADULT LEARNING PRINCIPALS IN MY WORKPLACE
}

\author{
${\text { Athula Ratnayake }{ }^{1 *} \text {, Nelum Abeysekara }}^{2}$ \\ Specialist Registrar in Anaesthetics, Royal Wolverhampton Hospital, UK ${ }^{1}$, Speciality Doctor in Elderly \\ Care Medicine, University Hospital of North Staffordshire, $U K^{2}$ \\ *Corresponding author E-mail: athurat66@yahoo.co.uk
}

Key words: experience, self direction

"Give me a fish and I will eat for a day. Teach me to fish and I eat for a lifetime." Anon

As professionals in the medical field, we are all life -long learners. This is especially true in anaesthetics, where teaching and learning play a pivotal role in our skilled-based speciality.

In our early days of under graduate education in Russia, we were taught to observe, talk and examine as many patients as possible during our clinical attachments. This early part of our learning curve was interesting especially the initial teacher directed learning and then the gradual transformation to self-directed reading and learning by which we increased our knowledge and skills. When we became final year students we were heavily involved in teaching our juniors, formally and informally mainly focusing on bedside clinical skills.

When we started our post graduate training in Sri Lanka and specialised post graduate training in the United Kingdom, which involves teaching undergraduates, post graduates and other health care workers, we realised the lack of knowledge we have in teaching adults. We have been primarily interested in what students learn without much knowledge of how they learn, and the contextual force that shape their learning. Those are some of the observations we have made and techniques we have used to develop self-directed adult learners in our clinical setting in the University Hospital of North Staffordshire (UHNS).

\section{How adults learn? 'The learning cycle'}

According to David Kolb, adult learning is a cyclical process, with four stagers: concrete experience (or “do"), reflective observation (or “observe”), abstract conceptualization (or “think”), active experimentation (or “plan”) (Kolb’s learning cycle)

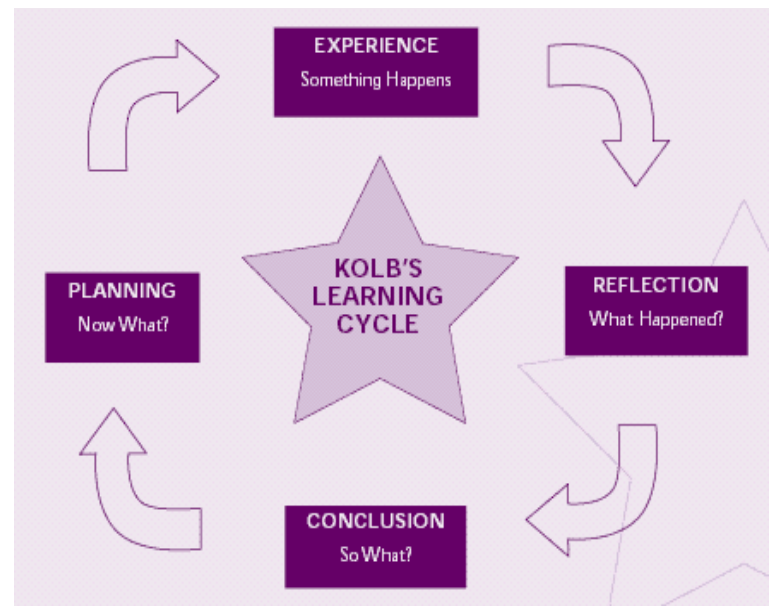

\section{Kolb's learning cycle}

The first stage, Concrete experience is where the learner actively experiences an activity e.g.: in the clinical setting: patient care in the recovery wards, oxygen therapy or prescribing pain relief medications. The second stage, reflective observation, the learner consciously reflects back on that experience. The third stage, abstract conceptualization (Concluding from experience), is where the learner attempts to conceptualize a theory or model of what is observed. At the fourth stage, active experimentation, the learner is trying to plan how to test a model or theory or plan for a forthcoming experience. Kolb's four-stage learning cycle shows how experience is translated through reflection into concepts, which in turn are used as guides for active experimentation and the choice of new experiences. This learning cycle is a continuous spiral, and that can begin at any one of four points. 


\section{The learning environment:}

Adult learners learn better in a stimulating learning environment. Knowles identify this as an establishment of physical and psychological climate of learning.

Education climate can subdivide into the physical environment, the emotional climate and the intellectual climate. Trainees are more likely to adopt deeper approaches to their learning and achieve quality learning outcomes when teaching provided for:

1. Intrinsic motivation and curiosity

2. Students independency

3. Student choice

4. Opportunities for work with the people

5. An environment that is challenging and, supportive and low threat

6. Frequent, constructive and useful feedbacks

7. Well structured and clear organisations

8. Active involvement in realistic learning tasks

9. An emphasis on high level of learning objectives

10. Practice and reinforcement

Marchese, Theodore. The Adult Learning in High Education and The Work Place; The New Conventions about Learning, http//www.newhorizones.org/Irnbus_marchese.ht $\mathrm{ml}$

\section{Stage 1: Self directed learners:}

Malcolm Knowles was convinced that adults learned differently to children - and that this provided the basis for a distinctive field of enquiry. Adult learners are expected to be selfdirected and independent. Different students have different abilities to be self-directed, and selfdirection can be taught.

Malcolm Knowles built his art and science of teaching adults on five assumptions:

1. Self-concept: Adults are independent and self directing.

2. Experience: They have accumulated a great deal of experience, which is a rich learning resource.

3. Readiness to learn. They value learning that integrates with the demands of their everyday life.

4. Orientation to learning. They are more interested in immediate, problem-centred approaches than in subject-centred ones.
5. Motivation to learn: They are more motivated to learn by internal drivers than by external ones. Knowles, M. S. et al (1984)

Candy (1987) usefully distinguished four meanings of the term "self-directed learning:" autonomy as a personal quality; autodidaxy as learning outside formal instruction; learner-control as (along with teacher-control) an essential consideration of formal instruction and self management as the willingness and capacity to conduct one's own education.

Learners act at different levels or stages of selfdirection and not all learners are ready to take responsibility for their own learning. It is important that teachers in the clinical setting recognise this and do not just leave learners to get on with learning entirely on their own.

\section{Stages of self-directed learning:}

Gerald Grow proposed stages of Self Directed Learning Model, built on work by Paul Heresy.

\begin{tabular}{|c|c|c|c|}
\hline Student & Teacher & Examples & \\
\hline Stage 1 & Dependent & $\begin{array}{l}\text { Authority, } \\
\text { Coach }\end{array}$ & $\begin{array}{l}\text { Coaching with } \\
\text { immediate } \\
\text { feedback. Drill. } \\
\text { Informational } \\
\text { lecture. Overcoming } \\
\text { deficiencies and } \\
\text { resistance. }\end{array}$ \\
\hline Stage 2 & Interested & $\begin{array}{l}\text { Motivator, } \\
\text { guide }\end{array}$ & $\begin{array}{l}\text { Inspiring lecture } \\
\text { plus guided } \\
\text { discussion. Goal- } \\
\text { setting and learning } \\
\text { strategies. }\end{array}$ \\
\hline Stage 3 & Involved & Facilitator & $\begin{array}{l}\text { Discussion } \\
\text { facilitated by } \\
\text { teacher who } \\
\text { participates as } \\
\text { equal. Seminar. } \\
\text { Group projects }\end{array}$ \\
\hline Stage 4 & $\begin{array}{l}\text { Self- } \\
\text { directed }\end{array}$ & $\begin{array}{l}\text { Consultant, } \\
\text { delegator }\end{array}$ & $\begin{array}{l}\text { Internship, } \\
\text { dissertation, } \\
\text { individual work or } \\
\text { self-directed study- } \\
\text { group. }\end{array}$ \\
\hline
\end{tabular}

The Staged Self-Directed Learning Model (SSDL) - Gerald Grow

The teacher's purpose is to match the learner's stage of self-direction and prepare the learner to advance to higher stages. 


\section{Stage 1: Learners of Low Self-Direction}

According to the SSDL model, dependent learners need an authority-figure to give them explicit directions on what to do, how to do it, and when. (Teacher-centred learning rather than Student centred) They either treat teachers as 'experts' who know what the student needs to do, or they passively slide through the educational system, responding mainly to teachers who "make" them learn. When coaching dependent learners, the teacher must first establish his credibility and authority. Teaching through the insight method: A different approach to teaching Stage 1 learners requires involving them in the design and content of the learning. Students begin from insight into who they are and what they want or need to learn. Adult educators customarily begin this way.

\section{Example 1:}

Lunch time teaching- tutorial for the house officers:

The Anaesthetic Department at Princess Royal Hospital provides a weekly lunch-time tutorial, during protected time, as part of the departmental education programme. I have been asked to give a teaching presentation on diagnosis, investigations and treatment of respiratory failure. It is a common clinical problem and this topic is very relevant to the anaesthetic trainees.

Junior house officers will have a variable knowledge base and are unlikely to prepare for the tutorial. They will be keen to acquire clinical experience and will not appreciate a 45 minutes of theorising. Many will be tired and perhaps hoping to catch up on some sleep. (They will need to have lunch as well!)

I presented a short clinical scenario of a patient I had seen in the A\&E department with type 2 respiratory failure. At the end each trainee is given the scenario on a handout together with four questions which need answering. Each trainee is asked to present one of the four questions in turn. (There were only 5 trainees!) The rest of the group was asked to justify their clinical decision as they present. This always promotes a lively discussion. In this way we manage to cover most of the important issues. At the end I gave a brief overview of the topic, covering the main learning points. A handout is provided, and evaluation forms were distributed.
The small group work over lunch creates an informal atmosphere. This allows the junior house officers to contribute to the discussion in a non threatening environment. On the other hand it is essential that they should have some prior knowledge. To be meaningful, the learners must have encountered the case scenario or something similar. This was a rewarding experience but to achieve success the teacher needs to plan carefully and to develop skills in group management.

\section{Stage 2: Learners of Moderate Self-Direction}

Learners at this stage go along if they understand why and the instructor provides direction and help. They are interested in what they are learning and respond well to motivational techniques. Stage 2 learners respond positively to personal interaction from the teacher--something not always true of Stage 1 learners.

\section{Example 2:}

Learning and teaching clinical skills in the bedside:

Junior house officers are attached to the department at UHNS to do their four months block in anaesthetics. At the end of their training period they have to have acquired competencies in preoperative assessment, airway management, fluid management, and basic anaesthetic skills, venous cannulations, intubation skills, airway management skills etc. Most of the competencies that they should achieve are of relevance to them to understand the role of the 'generic doctor 'and the others are more specific skills applied to anaesthetists. One of the junior house officers wanted to learn Central Venous Line (CVP) insertion. He had seen the procedure a few times before. After having had a discussion with him we decided to do a literature review on the subject including the indications, contraindications, complications and management of complications. This exercise helped to create a learning environment in a more organized manner with clearly stated learning goals. In the next step, we asked one of our consultants to demonstrate insertion of a CVP in a patient and we discussed the practical aspects. The third step was insertion of the CVP line under supervision, ensuring successful learning. We wanted to make sure the first experience with the procedure was as positive as possible providing close guidance. This task 
helped to cultivate responsibility, enthusiasm and enhancement of achievement-striving behaviour.

To teach at this stage, it is important to give clear explanations of why the skills are important and have a clear game plan of how to achieve the relevant skills. In this exercise trainees share the responsibility for planning and operating the learning experience.

\section{Stage 3: 'Involved learners' Learners of Intermediate Self-Direction}

Example 3:

One of the Year 3 Registrars was presented with a patient immediately post cardiac surgery who was profoundly hypovolemic. The team believed that this was a cardiac tamponade that should be treated surgically. However the heart sounds were not muffled, ECG amplitude remained stable on the 12 lead ECG, central venous pressure was low, and ventilation was not compromised. Registrar was convinced that this was a problem of hypovolemia even though fluids had been, and were being given. Continuing fluid and inotropes administration, he insisted upon Trans Oesophageal echo examination. This confirmed that hypovolemia was present. The senior consultant arrived and confirmed that the problem was hypovolemia. By this time the fluid resuscitation was correcting the situation and an unnecessary operation had been avoided.

Stage three learners have skill and knowledge, and they see themselves as participants in their own education. They are ready to explore a subject with a good guide. They will even explore some of it on their own. But they may need to develop a deeper self-concept, more confidence, more sense of direction, and a greater ability to work with (and learn from) others. Stage 3 learners will benefit from learning more about how they learn, such as making conscious use of learning strategies (Derry,1988/9).

It is of paramount importance that stage 3 learners develop critical thinking, individual initiative, and a sense of themselves as 'co-creators' of the culture that shapes them.

The trainer comes closest at this stage to being a participant in the learning experience. Teacher and trainee share in decision-making, with trainees taking on a bigger role. The teacher concentrates on facilitation and communication and supports trainees in using the skills they have.

\section{Stage 4: Learners of High Self-Direction}

Stage 4 self-directed learners set their own goals and standards-with or without help from experts. They use experts, institutions, and other resources to pursue these goals. Being independent does not mean being a loner; many independent learners are highly social and belong to clubs or other informal learning groups.

Learners at this stage are both able and willing to take responsibility for their learning, direction, and productivity. They exercise skills in time management, project management, goal-setting, self-evaluation, peer critique, information gathering, and use of educational resources. The Stage 4 teacher's role is not to teach subject matter but to cultivate the student's ability to learn.

\section{Learning styles:}

Different people learn differently and learning is more effective if they are aware of their own learning style preferences. Honey and Mumford (1992) described four learning styles: Activist, Reflector, Theorist and Pragmatist. The categories follow the learning modes defined by Kolb (1984): Active Experimentation, Reflective Observation, Abstract Conceptualization and Concrete Experience. Trainees can find out their preferred learning style or styles by completing a selfdescription questionnaire. This comprises 80 statements, it stresses there are no right or wrong answers, and it asks the respondent to mark a tick against a statement if they agree with it more than they disagree with it, a cross if they disagree more than they agree. The scoring reveals the person's strength of preference for each of the four learning styles. Those who like active learning tick statements such as: I often act without considering the possible consequences, I actively seek out new experiences, I enjoy being the one that talks a lot and I'm usually one of the people who put life into a party. Reflectors agree with statements such as: I like the sort of work where I have time for thorough preparation and I'm always interested to find out what people think. Theorists tick statements such as: I tend to solve problems using a step-by-step approach and in discussions with people I often find I am the most dispassionate and objective. Pragmatists agree with: What matters 
most is whether something works in practice and I do whatever is expedient to get the job done. In our clinical setting it is important and helpful to know the learners learning style and our own style as a teacher. Over the period of time the learning style can shift from one to the other. Study skills courses often ask students to complete learning style questionnaires to increase their awareness of their preferred approach.

The challenges to teaching self directed learning in the hospital setting:

'The provision of teaching in the clinical setting in the UK remains an area of concern. A lack of appropriate teacher education, Time pressures, a lack of recognition and reward, Funding and support are some of the identified problems in this regard."

Department of Health (2002) Workforce Development Confederations: Functions, accountabilities and working relationships, $\mathrm{DOH}$, London.

All doctors are obligated to teach, yet there are no mandatory teacher education programmes and doctors have traditionally not received any formal training or teaching qualifications (eg postgraduate certificate in education). A lack of appropriate teacher education leads to problems with teaching methods: lack of clear objectives, over-emphasis on factual recall rather than on development of problem solving skills, the use of passive observation rather than active participation of learners, and teaching being pitched at the wrong level.

There are a number of practical difficulties that limit the effectiveness of teaching in the medical profession including reduced opportunities to teach (shorter hospital stays; patients too ill or too frail; more patients refusing consent), insufficient resources and a lack of 'teacher friendly' clinical environments.

With increased patient and administrative loads, and the requirement to conduct research, doctors have a number of competing demands that often mean there is insufficient time for preparation and teaching. Providing anaesthetic services in the clinical setting are very demanding and stressful in our busy University Hospital. There is always time pressure and conflict between training and service requirements. With the implementation of The European working time directive, these pressures are likely to continue to increase.

\section{References}

1. Gerald G., (1991)"Teaching Learners to be SelfDirected", Adult Education Quarterly, Vol. 41, No. 3, pp. 125-149.

2. Department of Health (2002) Workforce Development Confederations: Functions, accountabilities and working relationships, DOH, London.

3. Mohanna, K, Wall, D. Chambers, R. (2004) Teaching Made Easy, A Manual for Health Professionals, 2nd Ed. UK, Radcliffe Medical Press Ltd.

4. McNamara, R. (1997)[Online] Strong Value of SelfDirected Learning in the Workplace: How Supervisors and Learners Gain Leaps in Learning www.managementhelp.org/trng_dev/methods/slf_dr ct.htm[14/10/200]

5. Kolb. D. A. and Fry, R. (1975) 'Toward an applied theory of experiential learning; in C. Cooper (ed.) Theories of Group Process, London: John Wiley

6. Kolb, David A. 1984. Experiential Learning: Experience as the Source of Learning and Development. Prentice-Hall, Inc., Englewood Cliffs, N.J.

7. Knowles, M. S. et al (1984) Andragogy in Action. Applying modern principles of adult education, San Francisco: Jossey Bass

8. Smith, M. K. (2007) [Online] 'Malcolm Knowles, informal adult education, self-direction and anadragogy', the encyclopaedia of informal education,www.infed.org/thinkers/etknowl.htm.[14/10/2007]

9. Cannon ,R. Newble ,D.(200)Handbook for Teachers in Universities and Collegers, 4th Ed. Bell \& Bain Ltd, Glasgow

10.Boud, D. (1993) Developing Student Autonomy in Learning, 2nd Ed. UK, Kogan Page Ltd.

11.Biggs,j.(2003)Teaching for Quality Learning at University, $2^{\text {nd }}$ Ed, UK, SHRE and Open University Press.

12.Light, G and Cox, Roy. (2001)Learning and Teaching in Higher Education, London: Paul Chapman Publishing 